\title{
FORMULASI, UJI SIFAT FISIK DAN UJI AKTIVITAS MASKER PEEL OFF TEPUNG BERAS HITAM (Oriza sativa L. var Indica)
}

\author{
Mely Nastiti $^{1 *}$, Desy Nawangsari ${ }^{1}$, Dina Febrina ${ }^{1}$ \\ ${ }^{1}$ Universitas Harapan Bangsa, Purwokerto, Indonesia \\ *corresponding author \\ Email: melynastiti19@gmail.com
}

Diterima : 09 September 2021

Direvisi : 20 September 2021

Publikasi : 20 Oktober 2021

doi:10.52216/jfsi.vol4no2p58-67

\begin{abstract}
Black rice (Oriza sativa L. var Indica) is a local variety that contains anthocyanin pigments. Anthocyanins are antioxidants that have a positive effect on health. Peel off face mask is a face mask that has the advantage that it is easy to find like an elastic membrane. This study aims to determine the physical evaluation of the preparation, preparation, and antioxidant activity of the black rice flour peel off mask preparation. This research method was carried out experimentally, the data were analyzed by One Way ANOVA method with sig value > 0.05. The ingredients used are black rice flour, gelatin, glycerin, HPMC, triethanolamine, nipagin, nipasol and akuades. Evaluation of the preparation includes organoleptic test, $\mathrm{pH}$ test, dispersion test, and dry time test, while the antioxidant test includes making 40 ppm DPPH solution, determining the maximum length of DPPH, making peel off gel mask test solution, measuring antioxidant activity of peel off mask samples, manufacture of vitamin $C$ solution, measurement of antioxidant activity of vitamin $C$, percentage of inhibition of the IC50 value and measurement of blank absorption. The conclusion of this research is on the physical properties test, namely organoleptic with the same formulation of color, smell and shape. The resulting $\mathrm{pH}$ value enters the $\mathrm{pH}$ range. The spreadability of the three formulations is only formula 3 which does not enter the range. The time of the three formulations has a value that enters the normal range. The black rice flour peel off mask preparation test had a significant difference to the spreadability test of f1 ( $p$-value<0.05), but there was no significant difference between $f 2$ and 3 (p-value>0.05). Antioxidant test there is no significant difference ( $p$-value $>0.05$ ).
\end{abstract}

Keywords: Antioxidant, Black rice, dan Peel off mask.

\section{Intisari}

Beras hitam (Oriza sativa L. var Indica) merupakan varietas lokal yang mengandung pigmen antosianin. Antosianin bersifat sebagai antioksidan yang berefek positif bagi kesehatan. Masker wajah peel off adalah masker wajah yang memiliki keunggulan yaitu mudah dilepaskan seperti membran elastis. Penelitian ini bertujuan untuk mengetahui evaluasi fisik sediaan, stabilitas sediaan, dan aktivitas antioksidan sediaan masker peel off tepung beras hitam. Metode penelitian ini dilakukan secara eksperimental, data dianalisis dengan metode One Way ANOVA dengan sig >0,05. Bahan yang digunakan yaitu tepung beras hitam, gelatin, gliserin, HPMC, triethanolamin, nipagin, nipasol dan akuadest. Evaluasi sediaan meliputi uji organoleptik, uji pH, uji daya sebar, dan uji waktu kering, sedangkan pada uji antioksidan meliputi pembuatan larutan DPPH 40 ppm, penetapan panjang gelombang maksimum DPPH, pembuatan larutan uji masker gel peel off, pengukuran aktivitas antioksidan sampel masker peel off, pembuatan larutan vitamin $C$, pengukuran aktivitas antioksidan vitamin $C$, penentuan persen inhibisi dari nilai $I_{50}$ dan pengukuran serapan blanko. Kesimpulan dari 
penelitian ini adalah pada uji sifat fisik yaitu organoleptik ketiga formulasi memiliki warna, bau dan bentuk yang sama. Nilai $\mathrm{pH}$ yang dihasilkan memasuki rentang $\mathrm{pH}$. Daya sebar ketiga formulasi hanya formula 3 yang tidak memasuki rentang. Waktu mengering ketiga formulasi memiliki nilai yang memasuki rentang normal. Uji stabilitas sediaan masker peel off tepung beras hitam memiliki perbedaan nyata yang signifikan terhadap uji daya sebar f1(p-value<0,05), namun tidak terdapat perbedaan nyata yang signifikan terhadap f2 dan 3 (p-value>0,05). Uji antioksidan tidak terdapat perbedaan nyata yang signifikan ( $p$-value $>0,05$ ).

Kata kunci: Antioksidan, Beras hitam, dan masker peel off.

\section{Pendahuluan}

Indonesia merupakan negara tropis yang penuh dengan limpahan sinar matahari sepanjang tahunnya. Sinar matahari terdiri atas sinar dengan panjang gelombang 100-400 nm yang disebut dengan sinar ultraviolet (UV) (Hendriyanto, 2010). Radiasi UV memiliki banyak efek negatif terhadap kulit, baik secara langsung maupun tidak langsung (Wadoe et al., 2020).

Salah satu dampak negatif dari paparan sinar UV yaitu menyebabkan terjadinya penuaan dini yang ditandai dengan kusam, kering dan keriput (Isfardiyana dan Safitri, 2014). Penuaan dini dapat di atasi dengan antioksidan dengan cara melindungi kulit dari kerusakan oksidasi (Haerani et al., 2018). Salah satu tanaman yang mengandung aktivitas antioksidan kuat yaitu beras hitam. Nilai IC $_{50}$ pada tepung beras hitam yaitu 20,178 ppm (Muktisari dan Hartati, 2018).

Menurut Arifin (2019) warna ungu kehitaman beras ini berasal dari sumber antosianin, suatu zat turunan polifenol yang mempunyai aktivitas antioksidan. Antioksidan untuk perawatan kulit wajah lebih baik diformulasikan dalam bentuk topikal dibandingkan dengan oral karena zat aktif akan berinteraksi lebih lama dengan kulit wajah (Kartikasari dan Anggraini, 2018). Salah satu sediaan antioksidan topikal dapat berupa sediaan masker gel peel off.

Masker gel peel off merupakan masker wajah dalam bentuk gel yang praktis untuk digunakan karena setelah sediaan mengering dapat diangkat secara langsung dari kulit wajah (Setiawati dan Sukmawati, 2019). Kosmetik wajah dalam bentuk masker gel peel off bermanfaat dalam merelaksasi otot-otot wajah, sebagai pembersih, penyegar, pelembab dan pelembut bagi kulit wajah (Sulastri dan Chaerunisaa, 2018). Oleh karena itu, peneliti tertarik untuk membuat formulasi masker gel peel off tepung beras hitam serta melakukan pengujian antioksidan sediaan masker gel peel off tepung beras hitam.

\section{Metode Penelitian}

2.1. Alat dan Bahan

Alat yang digunakan untuk penelitian ini adalah ayakan mesh 80, batang pengaduk, cawan porselin, gelas kimia (pyrex), gelas ukur (pyrex), hot plate (thermo scientific, type SP 88857105), pipet tetes, sendok tanduk, lemari pendingin (sharp), termometer, timbangan digital (kenko), oven (memmert UN 30), stopwatch, sudip, alat uji daya lekat, alat uji daya sebar, objek glass, spektrofotometer UV-Visible (Biobase BKD590), Vortex, botol vial, dan tabung reaksi. Bahan yang digunakan untuk penelitian ini adalah akuades, gelatin kualitas pharmaceutical, HPMC kualitas pharmaceutical, kertas perkamen, $\mathrm{pH}$ universal, nipagin kualitas pharmaceutical, nipasol kualitas pharmaceutical, beras hitam, gliserin kualitas pharmaceutical, trietanolamin kualitas pharmaceutical (Petronas), metanol p.a (EMSURE), DPPH p.a (Sigma-Aldrich), dan aluminium foil.

\subsection{Determinasi tanaman}

Determinasi beras hitam (Oriza Sativa L. var Indica) dilakukan dengan tujuan untuk membuktikan kebenaran bahan beras hitam (Oriza sativa L. var Indica) yang digunakan.

\subsection{Pembuatan tepung beras hitam}

Beras hitam digiling dalam penggiling hingga diperoleh tepung beras hitam yang halus. Kemudian tepung beras hitam diayak dengan pengayak berukuran pori 80 mesh. Selanjutnya, 
tepung beras hitam ditimbang (Muktisari dan Hartati, 2018).

\subsection{Formulasi}

Formulasi merupakan awal dari jalannya penelitian dimana peneliti harus menentukan formula yang sesuai dengan literatur yang ada. Penelitian dilakukan dengan membedakan konsentrasi zat aktif.

Tabel 1. Formulasi masker gel peel off tepung beras hitam

\begin{tabular}{cccc}
\hline Bahan & $\begin{array}{c}\text { Formula } \\
\mathbf{1}(\mathbf{\%})\end{array}$ & $\begin{array}{c}\text { Formula 2 } \\
(\mathbf{\%})\end{array}$ & $\begin{array}{c}\text { Formula 3 } \\
(\mathbf{\%})\end{array}$ \\
\hline $\begin{array}{c}\text { Tepung beras } \\
\text { hitam }\end{array}$ & 5 & 10 & 15 \\
Gelatin & 2,5 & 2,5 & 2,5 \\
HPMC & 5 & 5 & 5 \\
Gliserin & 2 & 2 & 2 \\
Triethanolamin & 2 & 2 & 2 \\
Nipagin & 0,18 & 0,18 & 0,18 \\
Nipasol & 0,02 & 0,02 & 0,02 \\
Akuades & 83,3 & 78,3 & 73,3 \\
\hline Keterangan: & Formula masker peel off @ 200 gram \\
(Karmila, 2018) serta sudah dimodifikasi dengan tepung \\
beras hitam.
\end{tabular}

\subsection{Pembuatan masker peel off tepung beras hitam}

Menurut Septiani (2011) cara pembuatan 200 gram masker gel peel off tepung beras hitam pada penelitian ini adalah dengan mengembangkan sebanyak 5 gram gelatin di atas hot plate dalam akuades pada suhu $80-90^{\circ} \mathrm{C}$ dengan pengadukan yang konstan hingga mengembang. (Larutan A) Selanjutnya kembangkan sebanyak 10 gram HPMC dalam akuades panas pada suhu $<40^{\circ} \mathrm{C}$ dengan pengadukan yang konstan hingga mengembang (Larutan B), larutkan sebanyak 0,3 gram nipagin dan 0,04 gram nipasol dalam $3 \mathrm{~mL}$ gliserin (Larutan C).Campurkan larutan $\mathrm{C}$ dan $\mathrm{A}$ aduk hingga homogen, dan tambahkan larutan B. Tambahkan sebanyak $30 \mathrm{~mL}$ triethanolamin. Tambahkan sebanyak 10 gram tepung beras hitam yang sebelumnya telah dilarutkan dalam akuades sedikit demi sedikit ke dalam larutan A, lalu diaduk hingga homogen.

\subsection{Evaluasi sifat fisik masker gel peel off}

\section{a. Organoleptik}

Sediaan masker gel peel off tepung beras hitam ditimbang sebanyak $2 \mathrm{~g}$ lalu diamati berdasarkan perubahan warna, bentuk, dan bau. Replikasi dilakukan sebanyak 3 kali pada masingmasing formula (Faisal, 2019).

b. $\mathrm{pH}$

Pengukuran $\mathrm{pH}$ dilakukan dengan cara mencelupkan $\mathrm{pH}$ universal ke dalam sediaan masker gel peel off tepung beras hitam, sebanyak $1 \mathrm{~g}$ sediaan dilarutkan dalam air dengan volume $10 \mathrm{~mL}$, kemudian diukur $\mathrm{pH}$-nya menggunakan $\mathrm{pH}$ universal. Diamati perubahan warna yang ditunjukkan pada kertas $\mathrm{pH}$ universal, lalu dicatat. Replikasi dilakukan sebanyak 3 kali pada masingmasing formula (Istiqomah dan Anindhita, 2018).

c. Daya sebar

Uji daya sebar dilakukan untuk menjamin pemerataan gel saat diaplikasikan pada kulit (Lubapepita dan Wijaya, 2021). Gel ditimbang sebanyak 0,5 gram kemudian diletakkan di tengah kaca bulat berskala. Di atas gel diletakkan kaca bulat lain atau bahan transparan lain dan pemberat sehingga berat kaca bulat dan pemberat 150 gram, didiamkan selama 1 menit, kemudian dicatat diameter penyebarannya. Daya sebar gel yang baik antara 5-7 cm. Replikasi dilakukan sebanyak 3 kali pada masing-masing formula (Sayuti, 2015).

\section{d. Waktu mengering}

Pengujian ini dilakukan dengan cara mengoleskan sediaan sebanyak 0,2 gram pada object glass hingga membentuk lapisan tipis dengan tebal $1 \mathrm{~mm}$. Ditunggu sampai kering dan dapat dikelupas. Dihitung waktu yang diperlukan. Replikasi dilakukan sebanyak 3 kali pada masingmasing formula (Fauziah et al., 2020).

\section{e. Uji stabilitas (metode cycling test)}

Stabilitas masker dapat diketahui dengan melakukan uji cycling test sebanyak 6 siklus. Masker disimpan pada suhu $5{ }^{\circ} \mathrm{C} \pm 2{ }^{\circ} \mathrm{C}$ selama 24 jam lalu dipindahkan ke dalam oven bersuhu $40{ }^{\circ} \mathrm{C}$ selama 24 jam. Waktu selama penyimpanan dua suhu tersebut dianggap satu siklus. Sediaan masker kemudian diamati perubahan warna, aroma, bentuk gel, $\mathrm{pH}$, daya sebar, waktu mengering. Uji aktivitas antioksidan dilakukan sebelum dan sesudah cycling test (Dantas et al., 2016). 
2.7. Tahap uji aktivitas antioksidan masker gel peel off tepung beras hitam

a. Pembuatan larutan DPPH $40 \mathrm{ppm}$

Serbuk DPPH ditimbang sebanyak $10 \mathrm{mg}$ kemudian dilarutkan dalam $100 \mathrm{~mL}$ metanol dalam labu ukur $100 \mathrm{~mL}$ sampai tanda batas kemudian kocok hingga homogen dan diperoleh larutan dengan konsentrasi 100 ppm. Kemudian diencerkan dengan cara dipipet $20 \mathrm{~mL}$ larutan DPPH konsentrasi 100 ppm masukkan ke dalam labu ukur $50 \mathrm{~mL}$ cukupkan dengan metanol sampai tanda batas kemudian kocok hingga homogen, sehingga diperoleh larutan dengan konsentrasi 40 ppm (Rosaini et al., 2019).

b. Penetapan panjang gelombang maksimum DPPH

Dipipet 3,8 $\mathrm{mL}$ larutan DPPH $40 \mathrm{ppm}$, dimasukkan ke dalam botol vial. Lalu ditambahkan metanol sebanyak $0,2 \mathrm{~mL}$ dan dihomogenkan dan mulut tabung ditutup dengan aluminium foil. Kemudian diinkubasi dalam ruangan gelap selama 30 menit. Tentukan spektrum serapannya menggunakan spektrofotometer UV-Vis pada panjang gelombang 400-800 nm dan tentukan panjang gelombang serapan maksimumnya (Rosaini et al., 2019). DPPH memberikan serapan kuat pada panjang gelombang $517 \mathrm{~nm}$ dengan warna violet gelap (Rosaini et al., 2019).

\section{c. Pembuatan larutan uji Masker gel peel off}

Ditimbang lebih kurang $250 \mathrm{mg}$ masker gel peel off tepung beras hitam, lalu dilarutkan dalam $25 \mathrm{~mL}$ metanol sehingga didapat konsentrasi 10000 ppm. Larutan ini merupakan larutan induk. Selanjutnya dibuat beberapa seri konsentrasi yaitu, 100 ppm, 300 ppm, 500 ppm, 700 ppm, dan 900 ppm dengan cara dipipet $0,1 \mathrm{~mL}, 0,3 \mathrm{~mL}, 0,5$ $\mathrm{mL}, 0,7 \mathrm{~mL}$ dan $0,9 \mathrm{~mL}$ kemudian dimasukkan dalam labu ukur $10 \mathrm{~mL}$ tambahkan metanol sampai tanda batas (Rosaini et al., 2019).

\section{d. Pengukuran aktivitas antioksidan sampel masker gel peel off}

Dari beberapa konsentrasi yang telah dibuat, kemudian di pipet sebanyak 0,2 mL, dimasukkan ke dalam botol vial, ditambahkan DPPH 40 ppm sebanyak 3,8 $\mathrm{mL}$, kemudian dikocok hingga homogen dan diinkubasi selama 30 menit. Selanjutnya larutan uji diukur serapannya menggunakan alat spektrofotometer UV Vis pada panjang gelombang $517 \mathrm{~nm}$, dilakukan sebanyak 3 replikasi (Rosaini et al., 2019).

\section{e. Pembuatan larutan Vitamin C}

Dibuat larutan stok 100 ppm dengan cara menimbang sebanyak $1 \mathrm{mg}$ vitamin $\mathrm{C}$, kemudian dilarutkan dengan metanol sambil diaduk dan dihomogenkan lalu dicukupkan volumenya hingga $10 \mathrm{~mL}$. Selanjutnya dibuat variasi konsentrasi 2 ppm, 4 ppm, 6 ppm, 8 ppm dan 10 ppm dengan cara dipipet $0,2 \mathrm{~mL}, 0,4 \mathrm{~mL}, 0,6 \mathrm{~mL}, 0,8 \mathrm{~mL}$ dan $1 \mathrm{~mL}$ kemudian dimasukkan dalam labu ukur 10 $\mathrm{mL}$ tambahkan metanol sampai tanda batas (Tria et al., 2019).

\section{f. Pengukuran aktivitas antioksidan Vitamin C}

Pengujian dilakukan dengan memipet $0,5 \mathrm{~mL}$ larutan vitamin $\mathrm{C}$ dari berbagai konsentrasi 2 ppm, 4 ppm, 6 ppm, 8 ppm dan 10 ppm. Kemudian masing-masing ditambahkan $3,5 \mathrm{ml}$ DPPH. Kemudian divortex dan diinkubasi pada ruangan gelap. Diukur absorbansinya pada panjang gelombang $517 \mathrm{~nm}$, dilakukan sebanyak 3 replikasi (Tria et al., 2019).

\section{g. Pengukuran serapan blanko}

Pengukuran dilakukan dengan memipet $4 \mathrm{~mL}$ DPPH. Selanjutnya divortex dan diinkubasi pada ruangan gelap selama 30 menit. Diukur absorbansinya pada panjang gelombang $517 \mathrm{~nm}$, dilakukan sebanyak 3 kali replikasi (Tria et al., 2019).

\subsection{Analisis data}

Analisis data pada penelitian ini dilakukan dengan uji One Way Anova terhadap uji pH, uji daya sebar, uji waktu mengering, uji stabilitas sediaan dan uji antioksidan masker peel off tepung beras hitam. Uji ANOVA untuk mengetahui perbedaan dari setiap formula dengan menggunakan program SPPS 28.0 (Priyanto, 2013).

\section{Hasil dan Pembahasan}

\subsection{Determinasi tanaman beras hitam}

Hasil determinasi tanaman beras hitam (Oriza sativa L. var Indica) adalah sebagai berikut: Kunci 
Determinasi: 1b-2b-3b-4a-5a- Familia: Gramineae 1b-2b-17a- Genus: Oryza. Berdasarkan hasil determinasi tersebut dapat diketahui bahwa beras hitam yang digunakan pada penelitian ini berasal dari spesies Oriza sativa L. var Indica.

\subsection{Tepung beras hitam}

Proses pembuatan tepung beras hitam meliputi penggilingan bahan baku dan pengayakan. Beras hitam digiling dalam penggiling hingga diperoleh tepung beras hitam yang halus. Beras hitam yang sudah halus diayak dengan pengayak 80 mesh. Pengayakan menggunakan ayakan 80 mesh bertujuan untuk memisahkan bagian tepung yang kasar dan yang halus sehingga diperoleh butiran tepung yang seragam (Siti dan Dewi, 2019). Selanjutnya, tepung beras hitam ditimbang. Tepung beras digunakan sebagai bahan aktif pada sediaan masker peel off tepung beras hitam dengan konsentrasi 5\%, 10\%, dan $15 \%$.

\subsection{Sifat fisik masker peel off tepung beras hitam}

Evaluasi sifat fisik gel masker peel off meliputi pemeriksaan organoleptik, $\mathrm{pH}$, pemeriksaan waktu kering, pemeriksaan daya menyebar yaitu sebagai berikut:

a. Uji organoleptik

Hasil uji organoleptik dari sediaan masker peel off tepung beras hitam dapat dilihat pada tabel 2.

Tabel 2. Hasil uji organoleptik

\begin{tabular}{cl}
\hline Formula & \multicolumn{1}{c}{ Organoleptik } \\
\hline 1 & Warna: putih susu \\
& Bau: khas tepung beras \\
& Bentuk: semi padat \\
& Warna: putih susu \\
& Bau: khat tepung beras \\
& Bentuk: semi padat \\
& Warna: putih susu \\
3 & Bau: khas tepung beras \\
& Bentuk: semi padat \\
\hline
\end{tabular}

Uji organoleptik meliputi bau, warna dan bentuk dari sediaan masker peel off tepung beras hitam yang diamati secara visual. Hasil pengujian organoleptik yang dibuat dengan perbedaan konsentrasi pada ketiga formulasi dengan tiga kali replikasi memiliki bau, warna, dan bentuk yang sama pada masing-masing formulasi. Hasil penelitian ini serupa dengan penelitian Karmila (2018) bahwa warna putih susu pada sediaan masker gel peel off tepung beras hitam dipengaruhi oleh bahan yang digunakan berwarna putih dan bening yaitu HPMC, nipagin, nipasol, tepung beras hitam, gliserin dan triethanolamin. Aroma khas tepung beras pada sediaan dipengaruhi oleh zat aktif yang digunakan yaitu tepung beras. Konsistensi semi padat dari ketiga formula berbeda-beda, hal ini dipengaruhi variasi konsentrasi zat aktif yang berbeda.

\section{b. Uji pH}

Hasil uji pH dari sediaan masker peel off tepung beras hitam dapat dilihat pada tabel 3 .

Tabel 3. Hasil uji pH sediaan masker peel off

\begin{tabular}{ccc}
\hline Formula & $\mathbf{p H} \pm \mathbf{S D}$ & Standar \\
\hline 1 & $5,66 \pm 0,57$ & \\
2 & $5,66 \pm 0,57$ & $4,5-6,5$ \\
3 & $5,33 \pm 0,57$ & \\
\hline
\end{tabular}

Uji $\mathrm{pH}$ bertujuan untuk mengetahui tingkat keasaman dari sediaan agar sesuai dengan $\mathrm{pH}$ sediaan topikal. Gel sebaiknya memiliki $\mathrm{pH}$ yang sesuai dengan $\mathrm{pH}$ kulit yaitu 4,5-6,5 karena jika gel memiliki $\mathrm{pH}$ yang terlalu basa maka dapat menyebabkan kulit menjadi kering atau bersisik, sedangkan jika $\mathrm{pH}$ terlalu asam akan menimbulkan iritasi kulit (Rosida et al., 2018).

Berdasarkan data yang diperoleh, hasil sediaan masker gel peel off tepung beras hitam yang dibuat dengan perbedaan konsentrasi zat aktif pada ketiga formulasi dengan tiga kali replikasi terjadi penurunan $\mathrm{pH}$. Dimana hasil yang didapat sesuai dengan penelitian Santoso (2020), bahwa penurunan $\mathrm{pH}$ disebabkan karena pengaruh suhu ruangan dan pengadukan yang tidak konstan. Penurunan $\mathrm{pH}$ disebabkan masuknya $\mathrm{CO}_{2}$ ke dalam wadah pada saat pengukuran dilakukan. Adanya $\mathrm{CO}_{2}$ yang bereaksi dengan air menyebabkan $\mathrm{pH}$ menjadi asam.

\section{c. Uji daya sebar}

Hasil uji daya sebar dari sediaan masker peel off tepung beras hitam dapat dilihat pada tabel 4 . Pengujian daya sebar sediaan masker gel peel off tepung beras hitam dimaksudkan untuk mengetahui kemampuan menyebar gel saat dioleskan pada kulit. Berdasarkan data yang diperoleh sediaan masker gel peel off yang dibuat 
dengan perbedaan konsentrasi zat aktif pada setiap formulasi hasil pengamatan ketiga formulasi memiliki daya sebar yang berbeda-beda. Formula 1 dan 2 dengan tiga kali replikasi masuk dalam rentang daya sebar yang baik. Daya sebar yang baik mengakibatkan kontak antara zat aktif dengan kulit menjadi luas, sehingga absorbsi zat aktif ke dalam kulit berlangsung cepat (Wardani, 2016).

Uji daya sebar formula 3 dengan tiga kali replikasi belum memenuhi syarat. Hasil penelitian ini sejalan dengan penelitian Karmila (2018) bahwa penggunaan bahan aktif dengan konsentrasi yang berbeda-beda pada sediaan masker peel off dapat mempengaruhi hasil daya sebar karena zat aktif yang digunakan berbentuk padat yang bersifat mengikat air, sehingga semakin tinggi konsentrasi zat aktif, maka konsistensinya semakin kental sehingga daya sebar sediaan semakin rendah. Penurunan daya sebar terjadi melalui meningkatnya ukuran unit molekul karena telah mengabsorpsi pelarut hingga cairan tersebut tertahan untuk mengalir dan menyebar.

Tabel 4. Hasil uji daya sebar sediaan masker peel off

\begin{tabular}{ccc}
\hline Formula & Daya Sebar $(\mathbf{c m}) \pm$ SD & Standar \\
\hline 1 & $6,43 \pm 0,11$ & \\
2 & $5,23 \pm 0,25$ & $5-7 \mathrm{~cm}$ \\
3 & $4,73 * \pm 0,11$ & \\
\hline
\end{tabular}

\section{d. Uji waktu kering}

Hasil uji waktu kering dari sediaan masker peel off tepung beras hitam dapat dilihat pada tabel 5.

Tabel 5. Hasil uji waktu kering sediaan masker peel off

\begin{tabular}{ccc}
\hline Formula & $\begin{array}{c}\text { Waktu kering (menit) } \\
\mathbf{\pm S D}\end{array}$ & Standar \\
\hline 1 & $23,36 \pm 0,06$ & \\
2 & $23,38 \pm 0,02$ & $15-30$ menit \\
3 & $23,39 \pm 0,06$ & \\
\hline
\end{tabular}

Waktu kering sediaan gel masker peel off yang baik, yaitu antara 15-30 menit (Fauziah et $a l .$, 2020). Berdasarkan data yang diperoleh, hasil sediaan masker gel peel off tepung beras hitam yang dibuat dengan perbedaan konsentrasi zat aktif pada ketiga formulasi dengan tiga kali replikasi memenuhi persyaratan uji waktu kering yang baik. Dari ketiga formula tersebut yang memiliki daya mengering lebih cepat yaitu formula 1. Hal ini serupa dengan penelitian Karmila (2018) bahwa zat aktif 5\%, memiliki kemampuan mengikat air yang lebih rendah, menyebabkan air mudah menguap sehingga mempercepat proses pengeringan masker gel peel off.

\subsection{Hasil evaluasi cycling test sediaan masker gel} peel off tepung beras hitam (Oriza sativa L. var Indica).

Hasil uji cycling test dengan parameter pengujian organoleptik, $\mathrm{pH}$, daya sebar, dan waktu kering pada formula 1 sediaan masker peel off tepung beras hitam dapat dilihat pada tabel 6 .

Tabel 6. Hasil uji cycling test formula 1

\begin{tabular}{|c|c|c|c|c|}
\hline \multirow[b]{2}{*}{ Siklus } & \multicolumn{4}{|c|}{ Pengujian } \\
\hline & $\begin{array}{l}\text { Organoleptik } \\
\text { (Warna, bau } \\
\text { dan bentuk) }\end{array}$ & pH & $\begin{array}{c}\text { Daya } \\
\text { sebar }(\mathrm{cm})\end{array}$ & $\begin{array}{l}\text { Waktu } \\
\text { kering } \\
\text { (Menit) }\end{array}$ \\
\hline 1 & $\begin{array}{l}\text { Putih susu, } \\
\text { khas beras, } \\
\text { semi padat }\end{array}$ & $5,66 \pm 0,57$ & $6,4 \pm 0,05$ & $25,21 \pm 1,54$ \\
\hline 2 & $\begin{array}{l}\text { Putih susu, } \\
\text { Khas beras, } \\
\text { Semi padat }\end{array}$ & $5,33 \pm 0,57$ & $6,4 \pm 0,10$ & $25,21 \pm 1,54$ \\
\hline 3 & $\begin{array}{l}\text { Putih susu, } \\
\text { khas beras, } \\
\text { semi padat }\end{array}$ & $5,66 \pm 0,57$ & $6,4 \pm 0,20$ & $25,21 \pm 1,54$ \\
\hline 4 & $\begin{array}{l}\text { Putih susu, } \\
\text { khas, beras, } \\
\text { semi padat }\end{array}$ & $5,66 \pm 0,57$ & $6,4 \pm 0,12$ & $25,21 \pm 1,54$ \\
\hline 5 & $\begin{array}{l}\text { Putih susu, } \\
\text { khas beras, } \\
\text { semi padat }\end{array}$ & $5,66 \pm 0,57$ & $6,4 \pm 0,05$ & $25,21 \pm 1,54$ \\
\hline 6 & $\begin{array}{l}\text { Putih susu, } \\
\text { khas beras, } \\
\text { semi padat }\end{array}$ & $5,66 \pm 0,57$ & $6,4 \pm 0,06$ & $25,21 \pm 1,54$ \\
\hline & p-value & 0,739 & $<0,001 *$ & 0,75 \\
\hline
\end{tabular}

Keterangan:

Data $\mathrm{pH}$, daya sebar dan daya waktu kering tercantum adalah nilai mean \pm SD

*Terdapat perbedaan hasil pengujian yang signifikan setiap siklus

Hasil uji cycling test dengan parameter pengujian organoleptik, $\mathrm{pH}$, daya sebar, dan waktu kering pada formula 2 sediaan masker peel off tepung beras hitam dapat dilihat pada tabel 7 . Hasil uji cycling test dengan parameter pengujian organoleptik, $\mathrm{pH}$, daya sebar, dan waktu kering pada formula 3 sediaan masker peel off tepung beras hitam dapat dilihat pada tabel 8. Cycling test merupakan pengujian pada sediaan dengan suhu 
penyimpanan yang berbeda dalam interval waktu tertentu dengan tujuan untuk mempercepat terjadinya perubahan yang biasanya terjadi pada kondisi normal (Hospita dan Berefek, 2017).

Tabel 7. Hasil uji cycling test formula 2

\begin{tabular}{|c|c|c|c|c|}
\hline \multirow[b]{2}{*}{ Siklus } & \multicolumn{4}{|c|}{ Pengujian } \\
\hline & $\begin{array}{c}\text { Organoleptik } \\
\text { (Warna, bau } \\
\text { dan bentuk) }\end{array}$ & pH & $\begin{array}{l}\text { Daya } \\
\text { sebar } \\
(\mathrm{cm}) \\
\end{array}$ & $\begin{array}{l}\text { Waktu } \\
\text { kering } \\
\text { (Menit) }\end{array}$ \\
\hline 1 & $\begin{array}{l}\text { Putih susu, khas } \\
\text { beras, semi padat }\end{array}$ & $5,66 \pm 0,57$ & $4,6 \pm 0,10$ & $24,69 \pm 0,8$ \\
\hline 2 & $\begin{array}{l}\text { Putih susu, Khas } \\
\text { beras, Semi } \\
\text { padat }\end{array}$ & $5,33 \pm 0,57$ & $4,6 \pm 0,10$ & $23,88 \pm 0,56$ \\
\hline 3 & $\begin{array}{l}\text { Putih susu, khas } \\
\text { beras, semi padat }\end{array}$ & $5,66 \pm 0,57$ & $4,4 \pm 0,20$ & $24,57 \pm 0,99$ \\
\hline 4 & $\begin{array}{l}\text { Putih susu, khas, } \\
\text { beras, semi padat }\end{array}$ & $5,66 \pm 0,57$ & $4,6 \pm 0,10$ & $24,19 \pm 0,61$ \\
\hline 5 & $\begin{array}{l}\text { Putih susu, khas } \\
\text { beras, semi padat }\end{array}$ & $5,66 \pm 0,57$ & $4,8 \pm 0,10$ & $24,09 \pm 0,52$ \\
\hline 6 & $\begin{array}{l}\text { Putih susu, khas } \\
\text { beras, semi padat }\end{array}$ & $5,33 \pm 0,57$ & $4,6 \pm 0,20$ & $25,04 \pm 0,51$ \\
\hline & p-value & 0,929 & $\mathbf{0 , 3 7 1}$ & 0,89 \\
\hline
\end{tabular}

Keterangan:

Data $\mathrm{pH}$, daya sebar dan daya waktu kering tercantum adalah nilai mean \pm SD

*Terdapat perbedaan hasil pengujian yang signifikan setiap siklus

Tabel 8. Hasil uji cycling test formula 3

\begin{tabular}{|c|c|c|c|c|}
\hline \multirow[b]{2}{*}{ Siklus } & \multicolumn{4}{|c|}{ Pengujian } \\
\hline & $\begin{array}{l}\text { Organoleptik } \\
\text { (Warna, bau } \\
\text { dan bentuk) }\end{array}$ & pH & $\begin{array}{c}\text { Daya } \\
\text { sebar }(\mathrm{cm})\end{array}$ & $\begin{array}{l}\text { Waktu } \\
\text { kering } \\
\text { (Menit) }\end{array}$ \\
\hline 1 & $\begin{array}{l}\text { Putih susu, khas } \\
\text { beras, Semi } \\
\text { padat }\end{array}$ & $5,66 \pm 0,57$ & $5,5 \pm 0,30$ & $25,21 \pm 1,54$ \\
\hline 2 & $\begin{array}{l}\text { Putih susu, khas } \\
\text { beras, semi padat }\end{array}$ & $5,66 \pm 0,57$ & $5,5 \pm 0,10$ & $25,21 \pm 1,54$ \\
\hline 3 & $\begin{array}{l}\text { Putih susu, khas } \\
\text { beras, semi padat }\end{array}$ & $5,66 \pm 0,57$ & $5,5 \pm 0,20$ & $24,57 \pm 0,99$ \\
\hline 4 & $\begin{array}{l}\text { Putih susu, khas } \\
\text { beras, semi padat }\end{array}$ & $5,66 \pm 0,57$ & $5,5 \pm 0,20$ & $24,52 \pm 0,98$ \\
\hline 5 & $\begin{array}{l}\text { Putih susu, khas } \\
\text { beras, semi padat }\end{array}$ & $5,66 \pm 0,57$ & $5,5 \pm 0,20$ & $24,03 \pm 0,74$ \\
\hline 6 & $\begin{array}{l}\text { Putih susu, khas } \\
\text { beras, semi padat }\end{array}$ & $5,66 \pm 0,57$ & $5,5 \pm 0,20$ & $27,01 \pm 0,59$ \\
\hline & p-value & 0,943 & 0,75 & 0,75 \\
\hline
\end{tabular}

Keterangan:

Data $\mathrm{pH}$, daya sebar dan daya waktu kering tercantum adalah nilai mean \pm SD

*Terdapat perbedaan hasil pengujian yang signifikan setiap siklus

Hasil pengujian stabilitas, diperoleh bahwa masker gel peel off tepung beras hitam pada formulasi 1 menunjukkan hasil pengujian $\mathrm{pH}$ dan waktu mengering ( $p$-value $>0,05)$, hal ini menunjukkan bahwa tidak terdapat perbedaan yang signifikan pada uji $\mathrm{pH}$ dan uji waktu mengering dalam pengamatan selama 6 siklus. Sedangkan hasil uji daya sebar sediaan masker gel peel off pada formulasi 1 terdapat perbedaan yang signifikan dalam pengamatan selama 6 siklus, hal ini serupa dengan penelitian Yudistira (2019) bahwa perbedaan daya sebar yang signifikan selama 6 siklus diakibatkan oleh suhu penyimpanan yang tidak stabil sehingga mempengaruhi stabilitas polimer HPMC yang menyebabkan kandungan air di dalam gel berkurang maupun bertambah karna bertambahnya kelembapan di dalam gel. Sedangkan pada formula 2 dan 3 menunjukkan hasil yang stabil dengan analisis One Way Anova (p-value $>0,05)$.

3.5. Hasil uji antioksidan sediaan masker gel peel off tepung beras hitam (Oriza sativa L. var Indica)

Hasil uji antioksidan sediaan masker peel off tepung beras hitam dapat dilihat pada tabel 9 .

Tabel 9. Data nilai $\mathrm{IC}_{50}$ vitamin $\mathrm{C}$, dan sampel sebelum dan sesudah cycling test

\begin{tabular}{ccccccc}
\hline \multicolumn{6}{c}{ Nilai IC50 (ppm) } \\
\hline $\begin{array}{c}\text { Vitamin } \\
\text { C }\end{array}$ & $\begin{array}{c}\text { Sebelum cycling } \\
\text { test }\end{array}$ & & & Sesudah cycling test \\
& \multicolumn{7}{c}{ F2 } & F3 & F1 & F2 & F3 \\
\hline 5,52 & 13 & 131,2 & 46 & 225, & 170,7 & 148,8 \\
& 7 & 0 & & 15 & 6 & 5 \\
\hline
\end{tabular}

Berdasarkan data yang diperoleh, nilai $\mathrm{IC}_{50}$ sediaan masker peel off tepung beras hitam lebih lemah dari vitamin C. Hal ini disebabkan karena vitamin $\mathrm{C}$ merupakan senyawa yang murni (Astuti, 2013). Sedangkan sediaan masker gel peel off tepung beras hitam mengandung berbagai macam bahan tambahan pada pembuatan sediaan. Pengujian aktivitas antioksidan sediaan gel masker peel off tepung beras hitam dilakukan sebelum dan sesudah cycling test.

Dari data yang diperoleh menunjukkan aktivitas antioksidan sediaan masker gel peel off sesudah cycling test memiliki aktivitas antioksidan sedang pada formula 2 dan aktivitas antioksidan lemah pada formula 3, sedangkan pada formula 1 nilai $\mathrm{IC}_{50}$ yang didapat tidak memasuki aktivitas rentang antioksidan. Hal ini menunjukkan bahwa aktivitas antioksidan sediaan masker gel peel off 
tepung beras hitam setelah dilakukan uji cycling test semakin lemah. Dari hasil tersebut dapat disimpulkan bahwa penyimpanan cycling test mempengaruhi penurunan aktivitas antioksidan dari sediaan hal tersebut karena perubahan suhu yang mempengaruhi struktur fisika dari sediaan namun juga mempengaruhi struktur kimia sediaan yang berpengaruh pada aktivitas zat aktif yang terkandung di dalamnya (Rompis et al., 2019).

Menurut Sunarmi dan Yulianto (2016) perubahan suhu memungkinkan sediaan masker peel off tepung beras hitam mengalami oksidasi sehingga menurunkan aktivitas antioksidan. Sedangkan Uji ANOVA One Way bertujuan untuk mengetahui perbedaan aktivitas antioksidan. Hasil yang diperoleh yaitu nilai asymp.sig (asymptotic signifance) 0,314 lebih besar dari 0,05 sehingga menunjukkan bahwa dari ketiga formula sediaan gel peel off tepung beras hitam tidak terdapat perbedaan aktivitas antioksidan yang signifikan.

\section{Kesimpulan}

Sifat fisik yang dihasilkan masker gel peel off tepung beras hitam meliputi: Organoleptik ketiga formulasi memiliki warna, bau dan bentuk yang sama. Nilai $\mathrm{pH}$ yang dihasilkan dari ketiga formulasi masing-masing memiliki $\mathrm{pH} 5,66 ; 5,66$; dan 5,33 hal ini memenuhi persyaratan uji $\mathrm{pH}$ masker peel off . Daya sebar ketiga formulasi hanya formula 3 yang tidak memasuki rentang daya sebar sediaan masker peel off. Waktu mengering ketiga formulasi memiliki nilai yang memasuki rentang normal dan dari ketiga formulasi yang nilai waktu mengering paling lama yaitu pada formulasi 3 .

Formulasi sediaan masker peel off tepung beras hitam setelah dilakukan uji cycling test berdasarkan analisis data menggunakan one way anova formulasi yang stabil selama 6 siklus yaitu formulasi 2 dan 3. Nilai $\mathrm{IC}_{50}$ sediaan masker gel peel off tepung beras hitam pada uji aktivitas antioksidan dengan metode DPPH sebelum cycling test formula 1 , formula 2 , dan formula 3 berturut-turut yaitu 137; 131,20; dan 46 ppm. Sedangkan, sesudah cycling test formula 1, formula 2, dan formula 3 berturut-turut yaitu 223,15; 170,76; dan 148,85 ppm.

\section{Daftar Pustaka}

Arifin, A. S. (2019). Antioxidant Activity of Pigmented Rice and Impact on Health. Jurnal Pangan, 28(1), 11-22. https://doi.org/10.33964/jp.v28i1.416

Astuti Amin, J. W. (2013). Uji Aktivitas Antioksidan Ekstrak Etanol Klika Faloak (Sterculia quadrifida R.Br). Fitofarmaka, 2(2), 111-114.

Dantas, M. G. B., Reis, S. A. G. B., Damasceno, C. M. D., Rolim, L. A., Rolim-Neto, P. J., Carvalho, F. O., Quintans-Junior, L. J., \& Da Silva Almeida, J. R. G. (2016). Development and Evaluation of Stability of a Gel Formulation Containing the Monoterpene Borneol. Scientific World Journal, 2016. https://doi.org/10.1155/2016/7394685.

Faisal, H. (2019). Uji aktivitas antioksidan ekstrak etanol buah okra (Abelmoschus esculentus L. Moench) dengan metode DPPH (1,1-difenil2-pikrilhidrazil) dan Metode ABTS (2,2azinobis-(3-Ethylbenzothiazoline-6-Sulfonic Acid). Ready Star, 2(1), 1-5.

Fauziah, Marwarni, R., \& Adriani, A. (2020). Formulasi dan Uji Sifat Fisik Masker Wajah Peel-Off dari Ekstrak Sabut Kelapa (Cocos nucifera L). Jurnal Riset Kefarmasian Indonesia, 2(1), 42-51.

Haerani, A., Chaerunisa, A., Yohana, \& Subarnas, A. (2018). Artikel Tinjauan: Antioksidan Untuk Kulit. Farmaka, Universitas Padjadjaran, Bandung, 16(2), 135-151.

Hospita, K., \& Berefek, L. Y. (2017). Formulasi Dan Uji Stabilitas Sediaan Gel Ekstrak Terpurifikasi Daun Paliasa (Kleinhovia Hospita L.) Yang Berefek Antioksidan. Pharmacon, 6(3), 157-169. https://doi.org/10.35799/pha.6.2017.16867.

Isfardiyana, S. H., \& Safitri, S. R. (2014). Pentingnya melindungi kulit dari sinar ultraviolet dan cara melindungi kulit dengan sunblock buatan sendiri. Jurnal Inovasi Dan Kewirausahaan, 3(2), 126-133. https://journal.uii.ac.id/ajie/article/view/7819.

Istiqomah, N., \& Anindhita, M. A. (2018). Pengaruh Penggunaan Hidroksi Propil Metil 
Selulosa (HPMC) sebagai Gelling Agent terhadap Sifat Fisik Masker Peel Off Ekstrak Daun Sirih (Piper betle L.). Pena Jurnal Ilmu Pengetahuan Dan Teknologi, 32(2), 49-58.

Karmila, N. rusli. (2018). Formulasi Dan Uji Efektivitas Masker Peel-off Pati Jagung ( Zea mays sacchrata ). Jurnal Ilmiah Manuntung, 4(1), 59-66.

Kartikasari, D., \& Anggraini, R. (2018). Formulasi Masker Gel Peel Off Ekstrak Etanol Umbi Bawang Dayak (Eleutherine bulbosa (Mill)Urb). Jurnal Ilmu Farmasi Dan Farmasi Klinik (JIFFK), 15(1), 01-11.

Lubapepita Triananda, A., \& Wijaya, A. (2021). Formulasi Dan Uji Fisik Sediaan Gel Ekstrak Daun Petai Cina (Leucaena leucocephala (Lam.) De. Wit) Dengan Basis Hydroxy Propyl Methyl Cellulose (HPMC). Jurnal Kefarmasian Akfarindo, 29-36. https://doi.org/10.37089/jofar.vi0.101

Muktisari, R. D., \& Hartati, F. K. (2018). Analisis Aktivitas Antioksidan Pada Beras Hitam dan Tepung Beras Hitam (Oryza sativa L.indica). Foodscitech, $\quad 1(1), \quad 20-27$. https://doi.org/10.25139/fst.v1i1.1002.

Nugraha, M. I., Tamrin, \& Asyik, N. (2018). Karakterisasi Sifat Fisik, Kimia, dan Aktivitas Antioksidan Pada Beras Merah Varietas Bulo Bulo Asal Kabupaten Kolaka Dan Kabupaten Konawe Selatan. Jurnal Sains Dan Teknologi Pangan, 3(3), 12831296.

Okik Hendriyanto, C. (2010). Pengaruh Intensitas Sinar Ultraviolet Dan Pengadukan Terhadap Reduksi Jumlah Bakteri E.coli. Envirotek: Jurnal Ilmiah Teknik Lingkungan, 2(1), 1823.

Priyanto, D. 2013. Seri CD Software Olah Data Statistik Dengan Program PSPP. Mediakom. Yogyakarta.

Rompis, F., Yamlean, P. V. Y., \& Lolo, W. A. (2019). Formulasi Dan Uji Efektivitas Antioksidan Sediaan Masker Peel-Off Ekstrak Etanol Daun Sesewanua (Cleodendron squamatum Vahl.). Pharmacon, $\quad 8(2), \quad 388$. https://doi.org/10.35799/pha.8.2019.29305.
Rosaini, H., Makmur, I., Putri, R. D., \& Sidoretno, W. M. (2019). Formulasi , Pengujian Aktivitas Antioksidan dan Antibakteri Sediaan Masker Gel Peel Off Ekstrak Etanol Herba Seledri (Apium graveolens L .). Jurnal Farmasi Higea, 11(2).

Rosida, Sidiq, H. B. H. F., \& Apriliyanti, I. P. (2018). Evaluasi Sifat Fisik Dan Uji Iritasi Gel Ekstrak Kulit Buah Pisang (Musa acuminata Colla). Journal of Current Pharmaceutical Sciences, 2(1), 131-135. https://journal.umbjm.ac.id/index.php/jcps/art icle/view/174.

Santoso, I., Prayoga, T., Agustina, I., \& Rahayu, W. S. (2020). Formulasi Masker Gel Peel-Off Perasan Lidah Buaya (Aloe Vera L.) Dengan Gelling Agent Polivinil Alkohol. Jurnal Riset Kefarmasian Indonesia, 2(1), 17-25. https://doi.org/10.33759/jrki.v2i1.33.

Sayuti, N. A. (2015). Formulasi dan Uji Stabilitas Fisik Sediaan Gel Ekstrak Daun Ketepeng Cina (Cassia alata L.). Jurnal Kefarmasian Indonesia, $\quad 5(2), \quad 74-82$. https://doi.org/10.22435/jki.v5i2.4401.74-82.

Septiani, S., Wathoni, N., \& Mita, S. R. mita. (2011). Formulasi Sediaan Masker gel Antioksidan Dari Ekstrak Etanol Biji Belinjo. Fakultas Farmasi Universitas Padjajaran, 24.

Setiawati, R., \& Sukmawati, A. (2019). Karakterisasi Fisik dan Aktivitas Antioksidan Masker Wajah Gel Pell Off Yang Mengandung Sari Buah Naga (Hylocerus polyrhizus). Pharmacon: Jurnal Farmasi Indonesia, $\quad$ 15(2), 65-74. https://doi.org/10.23917/pharmacon.v15i2.72 45.

Siti, N., \& Dewi, F. (2019). Karakteristik fisikokimia dan fungsional pada tepung ubi kayu termodifikasi sebagai bahan baku beras analog.

Sulastri, A., \& Chaerunisaa, A. Y. (2018). Formulasi Masker Gel Peel Off Untuk Perawatan Kulit Wajah. Farmaka, 14(3), 1726.

Sunarmi, \& Yulianto, S. (2016). Formulasi Masker gel antioksidan mengandung ekstrak 
kulit buah naga merah ( hylocereus polyrhizus ). Kementerian Kesehatan Politeknik Kesehatan Surakarta Jurusan Jamu. Jurnal Terpadu Ilmu Kesehatan, 6(1), 93-100.

Tria Putri Alipha, Nurul Amalia, Nabilah Maya M, Y. P. (2019). Jurnal Ilmiah Kefarmasian. Jurnal Ilmiah Kefarmasian, 65-70.

Wadoe, M., Syifaudin, D. S., Alfianna, W., Aifa, F. F., D. P., N., Savitri, R. A., Andri, M. D., Ikhsan, N. D. M., Manggala, A., Fauzi, I. Q. K., Ayu, N., Mutrikah, M., \& Sulistyarini, A. (2020). Penggunaan Dan Pengetahuan Sunscreen Pada Mahasiswa Unair. Jurnal Farmasi Komunitas, 6(1), 1. https://doi.org/10.20473/jfk.v6i1.21821.

Wardani H, Oktaviani R, S. Y. (2016). Formulasi Masker Gel Peel-Off Ekstrak Etanol Umbi Bawang Dayak ( Eleutherine bulbosa (Mill.) Urb.) Husnul. Media Sains, 9(2), 167-173.

Yudistira, K. N. R. P. V. Y. Y. A. (2019). Antioksidan Sediaan Gel Dari Ekstrak Etanol Daun Sesewanua (Clerodendron squamatum Vahl ) Dengan Menggunakan Metode DPPH. 8, 298-305. 